УДК 336.1

Олена Стащук, доктор економічних наук, професор, Волинський національний університет імені Лесі Українки, завідувач кафедри кафедри фінансів, м.Луцьк, ORCID ID 0000-0003-2622-7353 e-mail: Staschuk.Olena@vnu.edu.ua

Микола Потрапелюк, здобувач ступеня «доктор філософії», за спеціальністю 072 Фінанси, банківська справа та страхування, Волинський національний університет імені Лесі Українки, м. Луцьк, ORCID ID 0000-0001-7952-7152 e-mail: by.mk4k525@gmail.com

https://doi.org/10.29038/2786-4618-2021-04-75-80

\title{
НАУКОВІ ОСНОВИ ФІНАНСОВОЇ БЕЗПЕКИ ДОМОГОСПОДАРСТВ
}

У статті узагальнено наукові підходи до визначення поняття фінансова безпека домогосподарств та 3'ясовано місце і роль фінансової безпеки домогосподарств у фінансовій безпеці держави та світу. На основі систематизації підходів науковців до формулювання сутності фінансової безпеки домогосподарств встановлено, що фінансова безпека домогосподарств в ієрархічній структурі відноситься до мікроекономічного рівня. До ієрархічної структури фінансової безпеки, окрім мікроекономічного рівня, також рекомендовано ввести такі рівні, як: нанорівень, мезорівень, макроекономічний рівень, глобальний рівень. Обгрунтовано, що фінансова безпека домогосподарств повинна відноситися до мікроекономічного рівня у системі фінансової безпеки. Запропоновано чинні підходи до визначення сутності фінансової безпеки домогосподарств класифікувати за двома напрямами: ресурсно-функціональний та стратегічно-цільовий. Запропоновано авторський підхід до трактування поняття «фінансова безпека домогосподарств» з урахуванням ресурснофункціонального підходу.

Ключові слова: фінансова безпека, домогосподарства, ієрархічна структура, мікроекономічний рівень, ресурсно-функціональний підхід, стратегічно-цільовий підхід.

Елена Стащук, доктор экономических наук, профессор, Волынский национальный университет имени Леси Украинки, г. Луцк

Николай Потрапелюк, соискатель степени «доктор философии», по специальности 072 Финансы, банковское дело и страхование Волынский национальный университет имени Леси Украинки, г. Луцк

\section{НАУЧНЫЕ ОСНОВЫ ФИНАНСОВОЙ БЕЗОПАСНОСТИ ДОМОХОЗЯЙСТВ}

В статье обобщены научные подходы к определению понятия финансовая безопасность домохозяйств и выяснено место и роль финансовой безопасности домохозяйств в финансовой безопасности государства и мира. На основе систематизации подходов ученых к формулированию сущности финансовой безопасности домохозяйств установлено, что финансовая безопасность домохозяйств в иерархической структуре относится к микроэкономическому уровню. В иерархическую структуру финансовой безопасности, кроме микроэкономического уровня, также рекомендуется ввести такие уровни, как: наноуровень, мезоуровень, макроэкономический уровень, глобальный уровень. Обосновано, что финансовая безопасность домохозяйств должна относиться к микроэкономическому уровню системы финансовой безопасности. Предложены 
действующие подходы к определению сущности финансовой безопасности домохозяйств классифицировать по двум направлениям: ресурсно-функциональное и стратегически-целевое. Предложен авторский подход к трактовке понятия «финансовая безопасность домохозяйств» с учетом ресурсно-функционального подхода.

Ключевые слова: финансовая безопасность, домохозяйства, иерархическая структура, микроэкономический уровень, ресурсно-функциональный подход, стратегически-целевой подход.

Olena Stashchuk,

Doctor of economics, Professor,

Lesya Ukrainka Volyn National University,

Lutsk

\section{Potrapeliuk Mykola,}

Postgraduate in specialty 072 Finance, Banking and Insurance Lesya Ukrainka Volyn National University,

Lutsk

\section{SCIENTIFIC FUNDAMENTALS OF FINANCIAL SECURITY OF HOUSEHOLDS}

The article summarizes scientific approaches to the definition of financial security of households and clarifies the place and role of financial security of households in the financial security of the state and the world. Based on the systematization of scientists' approaches to the formulation of the essence of financial security of households, it is established that the financial security of households in the hierarchical structure refers to the microeconomic level. In the hierarchical structure of financial security, in addition to the microeconomic level, it is also recommended to introduce such levels as: nanoscale, mesolevel, macroeconomic level, global level. In particular, the financial security of an individual citizen is included in the nanolevel; the microeconomic level includes financial security of enterprises and financial security of households; it is proposed to introduce financial security of the region, financial security of territorial communities and financial security of the industry to the mesoeconomic level; at the macroeconomic level, the financial security of the state is singled out, and at the global level, global financial security is included. It is substantiated that the financial security of households should be related to the microeconomic level in the hierarchical system of financial security.

It is proposed to classify the current approaches to determining the essence of financial security of households in two directions: resource-functional and strategic-target. It is substantiated that in accordance with the resourcefunctional approach, the financial security of households is considered in terms of adequacy of formation and efficiency of use of financial resources of households to ensure the implementation of their functions. It is noted that the strategic-targeted approach to the interpretation of the concept of financial security of households takes into account, first of all, the functions that financial security must perform in order to form opportunities for household development in future periods.

Based on a critical analysis of scholars' views on understanding the essence of the concept of "financial security of households", the author's approach to the interpretation of this concept taking into account the resource-functional approach. We believe that financial security of households is a system of financial, economic, social and legal relations that ensures the most efficient formation and use of financial resources of households to determine the mechanism for identifying and mitigating the negative impact of external and internal threats and maximizing household welfare.

Key words: financial security, households, hierarchical structure, microeconomic level, resource-functional approach, strategic-target approach.

Постановка проблеми та її значення. Структура фінансової системи України відображає фінансові відносини усіх суб’єктів господарювання, одним 3 елементів якої $\epsilon$ фінанси домогосподарств. В умовах формування ринкових економічних відносин домогосподарства відіграють важливу роль, що проявляється у їх двоїстому характері: з одного боку, домогосподарства виробляють ресурси, необхідні економіці; з другого боку - вони є кінцевими споживачами таких вироблених ресурсів. Тому, забезпечення фінансової безпеки домогосподарств має бути пріоритетним у безпековій політиці держави. 
Аналіз останніх досліджень і публікацій. Дослідження у сфері фінансової безпеки держави, підприємств i, зокрема, домогосподарств, здійснювали багато науковців та практиків, зокрема: Барановський О. І. [3], Варналій 3. С. [8], Воробйов Ю. М. [9], Ворошило В. В. [9], Зварич М. С. [1], Кізима Т. О. [4], Перепелиця М. О. [5], Півняк Ю. В. [7], Сніщенко Р. Г. [6], Твардовська Л. М., [7], Чабаненко М. В. [7] та інші. Віддаючи належне існуючим розробкам, варто відзначити про відсутність єдиного підходу до трактування поняття «фінансова безпека домогосподарств», структурування механізму іiі забезпечення, показників оцінювання. Особливо гостро проблематика забезпечення фінансової безпеки домогосподарств постає у періоди виникнення нових ризиків та загроз, зокрема й пандемії COVID-19.

Мета і завдання статті. Метою нашої роботи є систематизація підходів до ідентифікації поняття «фінансова безпека домогосподарств» та з'ясування iï місця і ролі у фінансовій безпеці держави та світу.

Виклад основного матеріалу дослідження 3 повним обгрунтуванням отриманих наукових результатів. Варналій 3. С. стверджує, що фінансова безпека - це захищеність фінансових інтересів суб'єктів господарювання на всіх рівнях фінансових відносин, забезпеченість домашніх господарств, підприємств, організацій та установ, регіонів, галузей, секторів економіки держави фінансовими ресурсами, достатніми для задоволення їх потреб і виконання зобов'язань [8, с. 35].

О. Д. Ладюк у своїх дослідженнях стверджує, що фінансову безпеку слід розглядати лише на макроекономічному та мікроекономічному рівнях. Зокрема, автор зазначає, що до макроекономічного рівня відноситься лише фінансова безпека держави, а до мікроекономічного рівня - фінансова безпека підприємств та фінансова безпека домогосподарств [11].

Б. І. Пшик, М. С. Зварич, Я. М. Кашуба та Л. Я. Слобода розрізняють 4 ієрархічні рівні фінансової безпеки, такі як:

- мегарівень: глобальна фінансова безпека;

- макрорівень: фінансова безпека держави4

- мезорівень: фінансова безпека регіону, галузі;

- мікрорівень: фінансова безпека домогосподарств та суб'єктів господарювання [10; с. 23].

Погоджуючись із науковцями, вважаємо, що місце фінансової безпеки домогосподарств можна представити так, як показано на рисунку 1. Водночас відзначимо, що розглядаючи фінансову безпеку, варто виділити такі іï рівні:

1) Нанорівень. До цього рівня вважаємо за доцільне віднести фінансову безпеку кожної окремої особи, під якою розуміємо той рівень формування фінансових ресурсів, котрий дозволить особі забезпечувати свою життєдіяльність, а також здійснювати заощадження фінансових ресурсів.

2) Мікроекономічний рівень. На даному рівні, вважаємо за доцільне відповідно до структури фінансової системи та особливостей руху фінансових ресурсів, виокремити фінансову безпеку суб'єктів господарювання та фінансову безпеку домогосподарств. Такий підхід пов'язаний із тим, що саме домашні господарства та окремі підприємства $є$ відіграють провідну роль у розвитку вітчизняної фінансової системи та економіки в цілому, а також та знаходяться у тісному взаємозв'язку з іншими складовими фінансової системи.

3) Мезоекономічний рівень. За вертикальним рівнем мезоекономічний рівень традиційно включає рівень адміністративно-територіальних одиниць та галузей, відтак вважаємо, що до фінансової безпека мезоекономічного рівня варто віднести фінансову безпеку регіонів, фінансову безпеку галузей та фінансову безпеку територіальних громад. Виокремлення останньої зумовлене реалізацією реформи децентралізації в Україні, що передбачає утворення нових суб'єктів фінансових відносин - територіальних громад.

4) Макроекономічний рівень. На даному рівні варто виокремити лише фінансову безпеку держави, яка відображає стан економіки в цілому, рівень ефективності формування та використання фінансових ресурсів держави та здатність до нейтралізації загроз фінансовій безпеці.

5) Глобальний рівень. На даному рівні варто виокремити світову фінансову безпеку як таку, що об'єднує фінансову безпеку національних економік світу та забезпечується механізмом фінансових 
відносин.

Варто також наголосити, що кожен наступний рівень залежить від ефективності функціонування попереднього рівня, інакше кажучи, чим вищою буде фінансова безпека макроекономічного та мезоекономічного рівня, тим вищим буде рівень фінансової безпеки домогосподарств та підприємств, установ, організацій і навпаки. Отже, чим більш стійкішою буде фінансова система України та чим більше мотиваційних стимулів буде створено для ефективної фінансової діяльності домогосподарств, тим вищим буде рівень фінансової безпеки останніх.

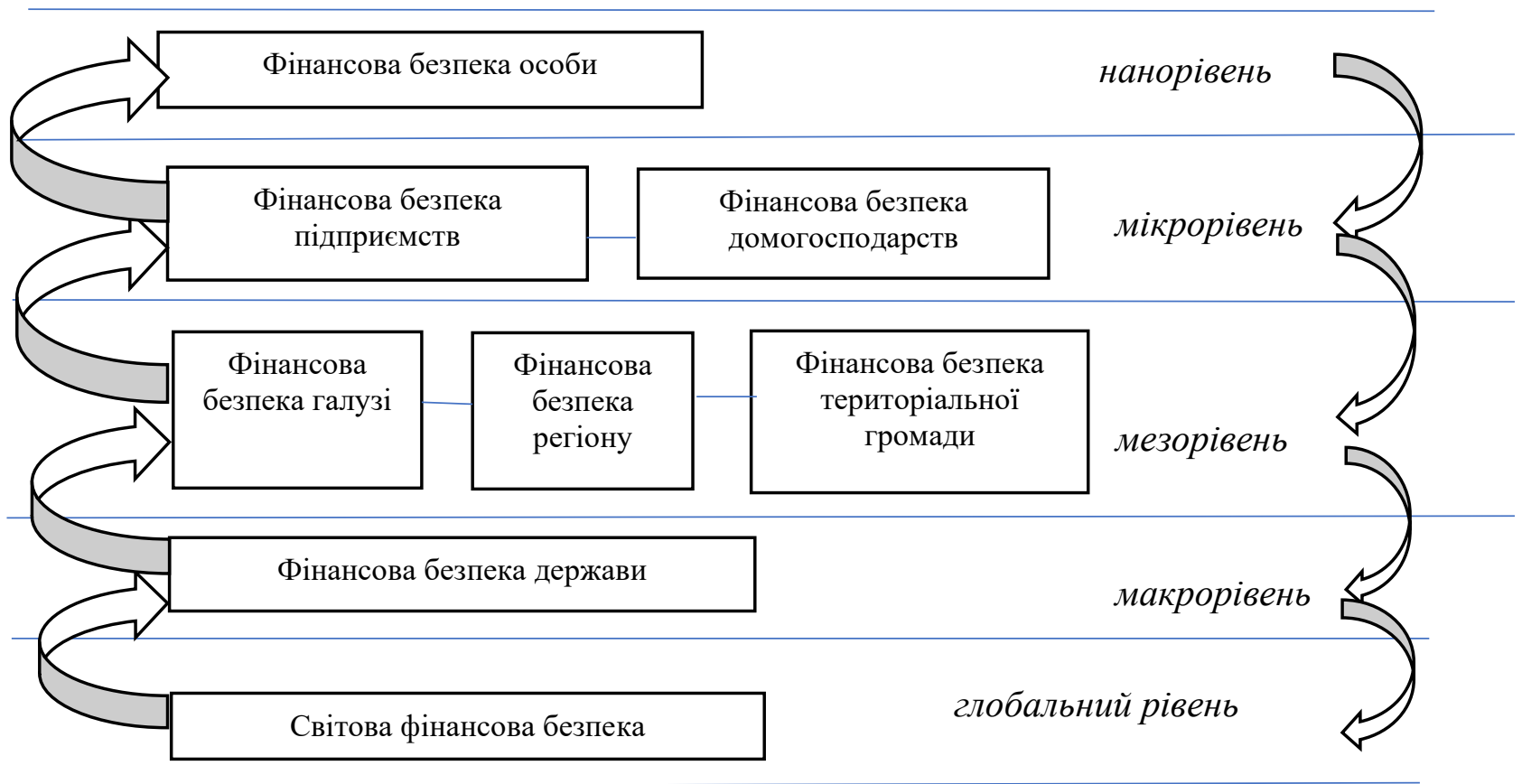

Рис.1. Місие фінансової безпеки домогосподарств в ієрархічній структурі. *

* складено автором на основі $[1 ; 2 ; 3]$

Звертаючись до наукової літератури у сфері фінансів, можемо бачити такі визначення поняття «фінансова безпека домогосподарств»:

1) сукупність соціально-економічних і правових відносин, що забезпечують такий стан фінансів домашніх господарств, при якому вони стійкі до зовнішніх загроз та ризиків, незалежні в ефективному формуванні і в раціональному використанні фінансових ресурсів для реалізації своїх функцій $[9$, с. 45];

2) система фінансово-економічних відносин, що забезпечує стан захищеності фінансів домашніх господарств від зовнішніх та внутрішніх загроз і небезпек у процесі їх життєдіяльності, зокрема формуванні та використанні фінансових ресурсів задля розвитку та достойного існування всіх членів домогосподарства [1, с. 131];

3) стан, що дає змогу зберігати стійкість до внутрішніх i зовнішніх загроз, i здатний задовольняти потреби сім'ї [7, с. 227];

4) економічні відносини 3 формування і використання грошових коштів 3 метою забезпечення матеріальних і соціальних умов життя членів господарства та їхнього відтворення [12, с. 102].

Критичний аналіз підходів до розуміння поняття фінансової безпеки домогосподарств дозволяє нам прийти до висновку, що усі підходи до ідентифікації зазначеного поняття можна поділити на дві групи: ресурсно-функціональний та структурно-цільовий. Відповідно до ресурсно-функціонального підходу, фінансова безпека домогосподарств розглядається з точки зору достатності формування та ефективності використання фінансових ресурсів домашніх господарств для забезпечення реалізації 
покладених на них функцій. Адептами такого підходу є такі вчені, як: Нагайчук Н. Г., Зварич М. С., Воробйов Ю. М., Ворошило В. В.

Разом 3 тим, стратегічно-цільовий підхід до трактування поняття фінансової безпеки домогосподарств враховує, насамперед, ті функції, які повинна виконувати фінансова безпека задля формування можливостей розвитку домашніх господарств у перспективних періодах. Прихильниками такого підходу є такі науковці, як: Твардовська Л. М., Півняк Ю. В., Чабаненко М. В. та інші.

Як бачимо, серед науковців відсутній єдино прийнятий підхід до трактування поняття «фінансова безпека домогосподарств». Вважаємо, що фінансова безпека домогосподарств - це сукупність фінансово-економічних, соціальних та правових відносин, що забезпечує стан найбільш ефективного формування та використання фінансових ресурсів домогосподарств 3 метою визначення механізму виявлення та нівелювання негативного впливу зовнішніх та внутрішніх загроз, а також максимізації рівня добробуту домогосподарств.

Висновки і перспективи подальших досліджень. Підсумовуючи вище зазначене, можна стверджувати, що фінансова безпека домогосподарств, не дивлячись на своє унікальне місце в системі фінансової безпеки держави, $є$ недостатньо дослідженою та вимагає розробки новітніх механізмів їі забезпечення з урахуванням нових викликів та загроз, що виникають у глобальному середовищі.

\section{Джерела та література}

1. Зварич M. C. Теоретичні підходи до визначення сутності фінансової безпеки домогосподарств. URL: http://www.ej.kherson.ua/journal/economic_15/1/35.pdf (дата звернення 2.12.2021)

2. Стащук О. В. Сучасна парадигма фінансової безпеки акціонерних товариств. Тернопіль: ТНЕУ, 2018. $398 \mathrm{c}$.

3. Барановський О.І. Філософія безпеки : монографія : у 2 т. К. : УБС НБУ, 2014. Т. 1 : Основи економічної і фінансової безпеки економічних агентів. $831 \mathrm{c}$.

4. Кізима Т.О. Фінанси домогосподарств: концептуальні засади теорії та практики: автореф. дис. ... на здобуття наук. ступеня док. екон. наук: спец. 08.00 .08 «Гроші, фінанси і кредит». Тернопіль, 2011. 36 с.

5. Перепелиця М.О. Національна безпека держави у фінансовій сфері: поняття й загрози існуванню. Науковий вісник Херсонського державного університету. Серія: Юридичні науки. 2016. Вип. 2 (2). С. 86-89.

6. Сніщенко Р.Г. Фінансова безпека домогосподарств у період нестабільності економіки. Вісник Кременчуиького національного університету імені Михайла Остроградського. Сер.: Економічні науки. 2014. № 1. C. $149-159$.

7. Твардовська Л.М., Півняк Ю. В., Чабаненко М. В. Проблема визначення економічної безпеки домашніх господарств в умовах ринкової економіки. Наукові записки Наиіонального університету «Острозька академія». Сер.: Економіка. 2012. Вип. 19. С. 226-229.

8. Економічна безпека: навч. посб. / за ред. З. С. Варналія. К. : Знання, 2009. 647 с.

9. Воробйов Ю.М., Ворошило В. В. Фінанси домашніх господарств у фінансовій системі держави: монографія. Сімферополь: ВД «АРІАЛ», 2013. 232 с.

10. Фінансова безпека домогосподарств в Україні: сучасні проблеми та механізм забезпечення / кол. авт. ; за заг. ред. д-ра екон. наук, проф. Б. І. Пшика. Львів : СПОЛОМ, 2020. 274 с.

11. Ладюк O. Д. Фінансова безпека: характеристика складників. URL: http://www.economy.nayka.com.ua/?op=1\&z=5280 (дата звернення 10.10 .2021 p.).

12. Нагайчук Н.Г. Уточнення змісту поняття «фінанси домогосподарств» у розрізі навчальної дисципліни «фінанси». Фінансовий простір. 2014. № 2. С. 100-105.

\section{References}

1. Teoretychni pidkhody do vyznachennia sutnosti finansovoi bezpeky domohospodarstv [Theoretical approaches to determining the essence offinancial security of households]. Naukovyj visnyku KhDU. Seriia Ekonomichni nauky, no. 15. ch. 1, pp. 130-132. [in Ukrainian].

2. Stashchuk O. V. (2018). Suchasna paradyhma finansovoyi bezpeky aktsionernykh tovarystv [Modern paradigm of financial security of joint stock companies]. Ternopil. TNEU, 398 p. [in Ukrainian]. 
3. Baranovs'kyy O.I. (2014). Filosofiya bezpeky : monohrafiya : u 2 t. [Philosophy of security: monograph: in 2 vols.] Vol. 1: Osnovy ekonomichnoyi i finansovoyi bezpeky ekonomichnykh ahentiv [Fundamentals of economic and financial security of economic agents], K. : UBS NBU. 831 p. [in Ukrainian].

4. Kizyma T.O. (2011). Finansy domohospodarstv: kontseptual'ni zasady teoriyi ta praktyky: avtoref. dys. ... na zdobuttya nauk. stupenya dok. ekon. nauk: spets. 08.00.08 «Hroshi, finansy i kredyt» [Household finance: conceptual principles of theory and practice: author's ref. dis. ... For science. degree doc. econ. Science: special. 08.00.08 "Money, finance and credit"], Ternopil, 2011. 36 p. [in Ukrainian].

5. Perepelytsya M.O. (2016). Natsional'na bezpeka derzhavy u finansoviy sferi: ponyattya y zahrozy isnuvannyu. [Naukovyy visnyk Khersons'koho derzhavnoho universytetu. Seriya: Yurydychni nauky - cientific Bulletin of Kherson State University. Series: Legal Sciences]. Vol. 2 (2). Pp. 86-89. [in Ukrainian].

6. Snishchenko R.H. (2014). Finansova bezpeka domohospodarstv u period nestabil'nosti ekonomiky. [Visnyk Kremenchuts'koho natsional'noho universytetu imeni Mykhayla Ostrohrads'koho. Ser.: Ekonomichni nauky - Bulletin of Kremenchug National University named after Mykhailo Ostrogradsky. Ser .. Economic Sciences]. Vol. 1. Pp. 149159. [in Ukrainian].

7. Tvardovs'ka L.M., Pivnyak YU. V., Chabanenko M. V. (2012). Problema vyznachennya ekonomichnoyi bezpeky domashnikh hospodarstv v umovakh rynkovoyi ekonomiky. [Naukovi zapysky Natsional'noho universytetu "Ostroz'ka akademiya». Ser.: Ekonomika.- Scientific notes of the National University "Ostroh Academy". Ser .. Economics], Vol. 19. pp. 226-229. [in Ukrainian].

8. Ekonomichna bezpeka: navch. Posb. (2009). [za red. Z. S. Varnaliya. - for ed. Z.S.Varnalia], K. : Znannya, 2009. 647 p. [in Ukrainian].

9. Vorobyov YU.M., Voroshylo V. V. (2013). Finansy domashnikh hospodarstv u finansoviy systemi derzhavy: monohrafiya [Finance of households in the financial system of the state: a monograph], Simferopol: VD "ARIAL", 2013. 232 p. [in Ukrainian].

10. Finansova bezpeka domohospodarstv v Ukrayini: suchasni problemy ta mekhanizm zabezpechennya [Financial security of households in Ukraine: current issues and support mechanism] (2020). Kol. avt. ; za zah. red. dra ekon. nauk, prof. B. I. Pshyka. Lviv: SPOLOM, 2020. 274 p. [in Ukrainian).

11. Ladyuk O. D. (2016). Finansova bezpeka: kharakterystyka skladnykiv [Financial security: characteristics of components]. Available at: http://www.economy.nayka.com.ua/?op=1\&z=5280 [in Ukrainian].

12. Nahaychuk N.H. (2014). Utochnennya zmistu ponyattya «finansy domohospodarstv» u rozrizi navchal'noyi dystsypliny «finansy». [Finansovyy prostir- Financial space]. № 2. P. 100-105. [in Ukrainian].

Стаття надійшла до редакції 20.11.2021 р. 